American Journal of Infectious Diseases 2 (1): 1-8, 2006

ISSN 1553-6203

(c) 2006 Science Publications

\title{
In vitro Antibacterial and Antifungal Activities of Nopalea cochenillifera Pad Extracts
}

\author{
${ }^{1}$ R. Gomez-Flores, ${ }^{1}$ P. Tamez-Guerra, ${ }^{1}$ R. Tamez-Guerra, ${ }^{1}$ C. Rodriguez-Padilla, ${ }^{1}$ E. Monreal-Cuevas \\ ${ }^{2}$ Leticia A. Hauad-Marroquin, ${ }^{2} \mathrm{C}$. Cordova-Puente and ${ }^{2} \mathrm{~A}$. Rangel-Llanas \\ ${ }^{1}$ Departamento de Microbiología e Inmunología, Laboratorio de Inmunología y Virología, Facultad de \\ Ciencias Biológicas Universidad Autónoma de Nuevo León, San Nicolás de los Garza, NL, México \\ ${ }^{2}$ Departamento de Química Biológica, Universidad Autónoma de Nuevo León
}

San Nicolás de los Garza, NL, México

\begin{abstract}
Effectiveness of botanical treatments has been recognized by many, but scientific validation on the beneficial use of plants is scarce. Nopalea pads are probably native to Mexico or Central America and are used for human consumption and for medicinal purposes. In this study, in vitro antibacterial and antifungal activities of fresh and dried Nopalea cochenillifera (NC) were investigated. MICs of fresh $\mathrm{NC}$ hexanic, chloroformic and ethanolic fractions against $C$. albicans were 250, 250 and $3.9 \mu \mathrm{g} \mathrm{mL}{ }^{-1}$ respectively; MICs of fresh NC against Salmonella enterica var. thyphimurium were 15.6, 62.5 and $3.9 \mu \mathrm{g} \mathrm{mL}^{-1}$ respectively; and MICs of fresh NC against Escherichia coli were 500, NA (no activity) and $3.9 \mu \mathrm{g} \mathrm{mL} \mathrm{m}^{-1}$ respectively. In addition, MICs of dried $\mathrm{NC}$ hexanic, chloroformic and ethanolic fractions against $C$. albicans were $31.2,31.2$ and $3.9 \mu \mathrm{g} \mathrm{mL}^{-1}$ respectively; MICs of dried NC against Salmonella enterica var. thyphimurium were 15.6, NA and 3.9 $\mu \mathrm{g} \mathrm{mL}{ }^{-1}$ respectively; and MICs of dried NC against Escherichia coli were NA, $62.5 \mu \mathrm{g} \mathrm{mL}^{-1}$ and NA respectively. The relevance of using fresh versus dried Nopalea cochenillifera pad extracts against in vitro microbial growth is discussed.
\end{abstract}

Key words: Nopalea cochenillifera, methanolic extract, hexanic extract, ethanolic extract, in vitro, antibacterial activity, antifungal activity, Salmonella enterica, E. coli, Candida albicans

\section{INTRODUCTION}

Nopalea tender young pads, also known as "nopalitos verdes", are probably native to Mexico or Central America. They are a good source of fruits ("tunas") and vegetables (nopalitos verdes) for human consumption, as well as fodder for cattle and other animals during the dry seasons. They are also used for medicinal purposes, in cosmetics, to produce dyes and as natural fences. These cacti belong to the subfamily Opuntioideae and comprise more than 200 species worldwide, 114 of which occur in Mexico ${ }^{[1-3]}$. They are commonly consumed as a fresh or cooked green vegetable in Mexico and in some parts of the United States $^{[4,5]}$. In Mexico, annual production of this vegetal is about 600,000 tons, being the area of Milpa Alta, D.F. the most important producer. In the United States, Nopalea cochenillifera (L.) Salm-Dyck clone 1308 is produced in the States of California and Texas, with an annual production of 5,000 tons ${ }^{[6,7]}$. This species is for the most part free of spines and spine-hairs ${ }^{[8,9]}$. Cactus pads usually contain about $92 \%$ water, $4-6 \%$ carbohydrate, $1 \%$ protein, $0.2 \%$ fat, $1 \%$ minerals, vitamin C (12.7 mg/100g fresh weight) and B-carotene $(12.9 \mu \mathrm{g} / 100 \mathrm{~g} \text { fresh weight })^{[10]}$.
In addition to the hypoglycemic property of cacti $^{[11]}$, there are few reports on the biological activity of Nopalea species. These plants have been used to treat rheumatism and other inflammatory problems and diarrhea, as well as a diuretic and analgesic, particularly for ear and tooth aches ${ }^{[12-16]}$. The anti-inflammatory principle was related to a $\beta$-sitosterol ${ }^{[17]}$. Nopalea cochenillifera was also shown to inhibit herpes simplex virus type 1 infection ${ }^{[18]}$. Despite these biological properties, validation of any antibiotic potential against bacterial and fungal species has not been reported yet.

The present study was undertaken to evaluate the effects of the methanolic, hexanic and ethanolic fractions of Nopalea cochenillifera pads on in vitro antimicrobial activity against Escherichia coli, Salmonella enterica var. thyphimurium and Candida albicans.

\section{MATERIALS AND METHODS}

Reagents, culture media and microbial strains: Sodium dodecyl sulfate (SDS), N,Ndimethylformamide (DMF) and 3-[4,5-dimethylthiazol2-yl]-2,5-diphenyltetrazolium bromide (MTT) were purchased from Sigma Chemical Co. (St. Louis, MO). Candida albicans (ATCC 32354) and Escherichia coli

Corresponding Author: $\quad$ Ricardo Gomez-Flores, Ph.D, Río Guadalquivir 402 B-Ote., Colonia del Valle, San Pedro Garza García, Nuevo León, México, C.P. 66220, Tel: (83)294110 x 6453, Fax: (83)524212 
(ATCC 25922) were purchased from the American Type Culture Collection (Rockville, MD) and Salmonella enterica var. thyphimurium was a foodborne native isolate. Extraction buffer was prepared by dissolving $20 \%(\mathrm{wt} / \mathrm{vol}) \mathrm{SDS}$ at $37^{\circ} \mathrm{C}$ in a solution of $50 \%$ each DMF and demineralized water and the $\mathrm{pH}$ was adjusted to 4.7 .

Preparation of Nopalea cochenillifera extract: The cactus material used in this study was identified as Nopalea cochenillifera, commonly known as "nopal verdura", by Marcela González-Vargas, Chief of the Herbarium of the Biological Sciences College at Autonomous University of Nuevo Leon, with a voucher specimen \# 024189 (UAN). It was obtained from a plantation in Villa de García, Nuevo León, located northeast of México. Fresh (not dried) Nopalea cochenillifera pads were cut in small pieces $(1000 \mathrm{~g})$ and were macerated in an Erlen Meyer flask with 3 liters of hexane, chloroform or ethanol for 7 days each at room temperature. After this, extracts were filtered (Whatman filters, Whatman International Ltd., Maidstone, England) and evaporated in a rotary evaporator Büchi (model R-114, Brinkmann Instruments Inc., Switzerland) to dryness obtaining respectively, $3.47 \mathrm{~g}, 1.63 \mathrm{~g}$ and $19.8 \mathrm{~g}$. In addition, dried pads were pulverized and $20 \mathrm{~g}$ were placed in 3 independent Soxhlet extractors (PYREX, model 3840LCO, Mexico) using hexane, chloroform or ethanol. After this, extracts were filtered (125-mm diameter Whatman filters and evaporated in a rotary evaporator Büchi to dryness obtaining respectively, $5.7 \mathrm{~g}, 5.32 \mathrm{~g}$ and $30.31 \mathrm{~g}$.

Microbicidal activity of $N$. cochenillifera extracts: We selected Candida albicans, Escherichia coli and Salmonella enterica var. thyphimurium because they are related to AIDS and gastrointestinal disorders. These strains were maintained and activated in specific culture media for each type of microorganism. We determined the percentage of microbial growth inhibition by Nopalea extract fractions in liquid medium by a colorimetric technique ${ }^{[19]}$. Candida albicans was activated by plating an aliquot in YM agar (Difco Laboratories, Detroit, Mich) for $24 \mathrm{~h}$ at $37^{\circ} \mathrm{C}^{[19]}$. Next, a loop of the culture was taken and suspended in YM broth (Difco, Becton Dickinson Microbiology Systems, Sparks, MD) and adjusted to $1 \times 10^{3}$ yeasts $\mathrm{mL}^{-1}$. Bacteria were cultured in Mueller-Hinton agar (Becton Dickinson de México, Estado de México) for $24 \mathrm{~h}$ at $37^{\circ} \mathrm{C}$, after which a single colony was taken and suspended in BHI broth (DIBICO, Co., pH 7.4, México $\mathrm{DF}$ ) at a concentration of $2 \times 10^{3}$ bacteria $\mathrm{mL}^{-1}$. Fifty microliters of the microbial suspensions were plated (in YM and BHI broths for yeasts and bacteria respectively) in flat-bottomed 96-well plates (Corning Incorporated, Corning, NY) in the presence or absence of serial dilutions $(1: 2)$ of the Nopalea extract $(50 \mu \mathrm{L})$ to be tested. Vehicle controls were also tested; they were shamed prepared and processed as if they contained Nopalea extracts. Plates were then incubated for $24 \mathrm{~h}$ (yeasts) or $6 \mathrm{~h}$ (bacteria) at $37^{\circ} \mathrm{C}$, after which the tetrazolium salt MTT was added to all wells at a final concentration of $0.5 \mathrm{mg} \mathrm{mL} \mathrm{m}^{-1}$ and plates were incubated for 4 additional hours. At the end of the incubation period, $50 \mu \mathrm{l}$ of extraction buffer were added to all wells and plates were incubated overnight at $37^{\circ} \mathrm{C}$. Optical densities resulting from dissolved formazan crystals, were then read in a microplate reader (Bio-Tek Instruments inc., EL-311, Winooski, VT) at $540 \mathrm{~nm}$.

Statistical analysis: The results were expressed as mean \pm SEM of triplicate determinations from three independent experiments. Statistical significance was assessed by the Student $t$ test.

\section{RESULTS}

Antimicrobial activity of fresh $N$. cochenillifera hexanic fraction: As observed in Fig. 1, Nopalea hexanic fraction did not alter C. albicans or E. coli growth; any observed inhibitory effect was due to the vehicle. However, this fraction caused 30 to 37 percent Salmonella enterica var. thyphimurium growth inhibition at the concentrations tested, but only the activity at concentrations $15.6,31.2$ and $62.5 \mu \mathrm{g} \mathrm{mL}^{-1}$ $(32.4,29.6$ and 29.8 percent growth inhibition respectively) were attributed to the effect of the fraction $(\mathrm{P}<0.05)$ when comparing the effect of the hexanic fraction versus the vehicle control (Fig. 1); any other inhibitory effect was due to the vehicle.

Antimicrobial activity of fresh $N$. cochenillifera chloroformic fraction: As observed in Fig. 2, Nopalea chloroformic fraction did not alter $C$. albicans growth; any observed inhibitory effect was due to the vehicle. This fraction, however, caused 20 to 30 percent Salmonella enterica var. thyphimurium growth inhibition at the concentrations tested, but only the activity at concentrations $62.5,125$ and $250 \mu \mathrm{g} \mathrm{mL}^{-1}$ (23.6, 24.3 and 28.1 percent growth inhibition respectively) were attributed to the effect of the fraction $(\mathrm{P}<0.05)$ when comparing the effect of the chloroformic fraction versus the vehicle control (Fig. $2)$; any other inhibitory effect was due to the vehicle. This fraction also caused 22 to 42 percent E. coli growth inhibition at the concentrations tested, but only the activity at $125 \mu \mathrm{g} \mathrm{mL} \mathrm{m}^{-1}$ (22.2 percent growth inhibition) was attributed to the effect of the fraction (P $<0.05$ ) when comparing the effect of the chloroformic fraction versus the vehicle control (Fig. 2); any other inhibitory effect was due to the vehicle.

Antimicrobial activity of fresh $N$. cochenillifera ethanolic fraction: As observed in Fig. 3, Nopalea ethanolic fraction caused 20 to 31 percent $C$. albicans growth inhibition at concentrations ranging from 
Am. J. Infect. Dis., 2 (1): 1-8, 2006
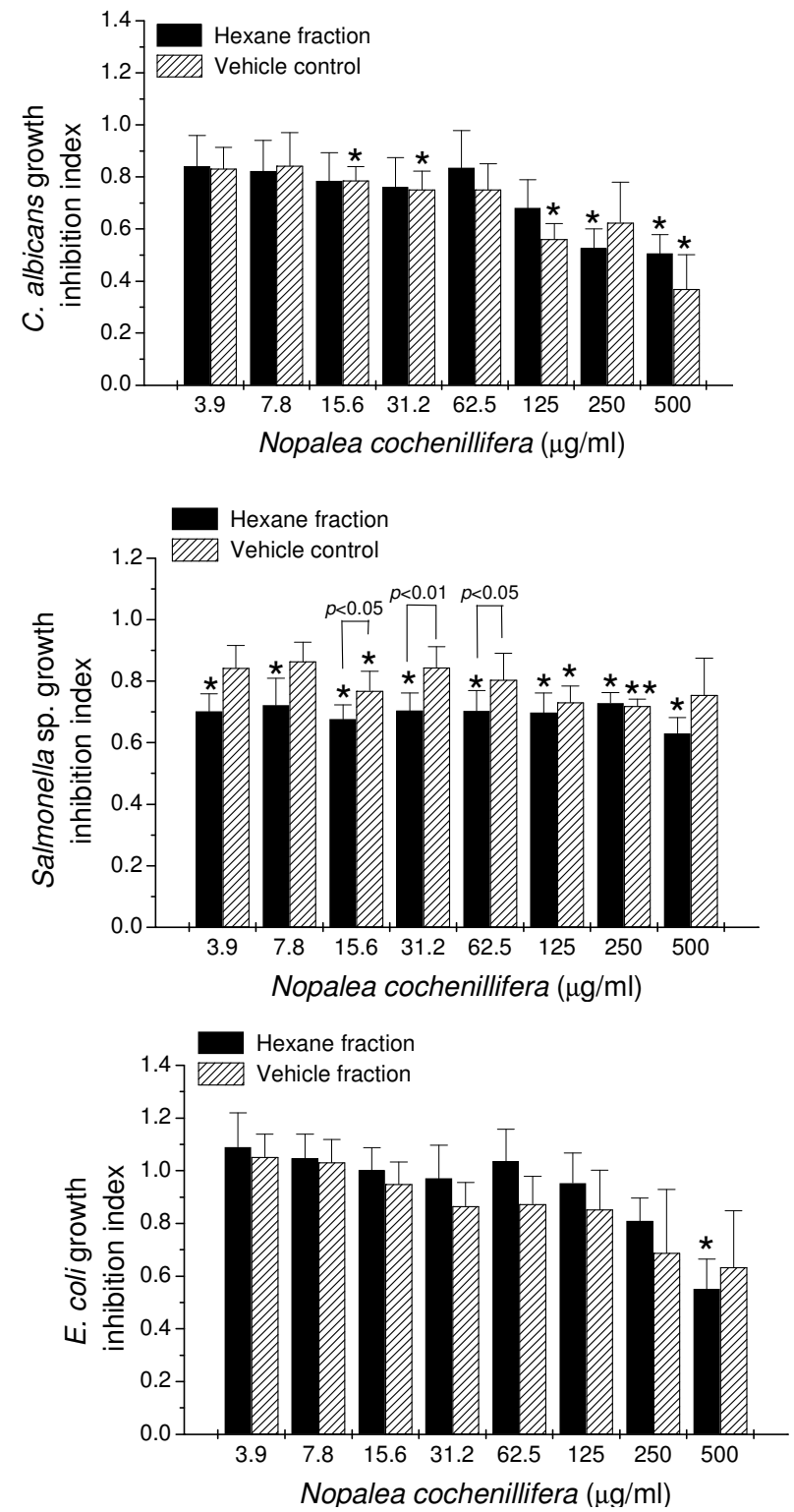

Fig. 1: Effect of fresh Nopalea hexanic fraction on C. albicans, Salmonella enterica and E. coli growth. Candida albicans was adjusted to $1 \times 10^{3}$ yeasts $\mathrm{mL}^{-1}$ in $\mathrm{YM}$ broth and bacteria were adjusted to $2 \times 10^{3}$ bacteria $\mathrm{mL}^{-1}$ in ICC broth as explained in the text. Then bacteria and yeasts were cultured in the presence or absence of various concentrations of the Nopalea extract or vehicle controls, for $24 \mathrm{~h}$ (yeasts) or $6 \mathrm{~h}$ (bacteria) at $37^{\circ} \mathrm{C}$, after which MTT was added to all wells and plates were incubated for 4 additional hours. At the end of the incubation period, extraction buffer was added to all wells and optical densities were read at $540 \mathrm{~nm}$ as detailed in the text. Data represent means \pm SEM of growth inhibition indexes of triplicates from 3 independent experiments. **, $\mathrm{P}<0.01$; $*, \mathrm{P}<0.05$ as compared with untreated control

3.9 to $250 \mu \mathrm{g} \mathrm{mL}-1$, but only the activity at concentrations 7.8, 15.6, 31.2 and $125 \mu \mathrm{g} \mathrm{mL}^{-1}$ (23.2, $30.6,21.6$ and 24.7 percent growth inhibition respectively) were attributed to the effect of this fraction $(\mathrm{P}<0.05)$ when comparing the effect of the ethanolic fraction versus the vehicle control (Fig. 3);
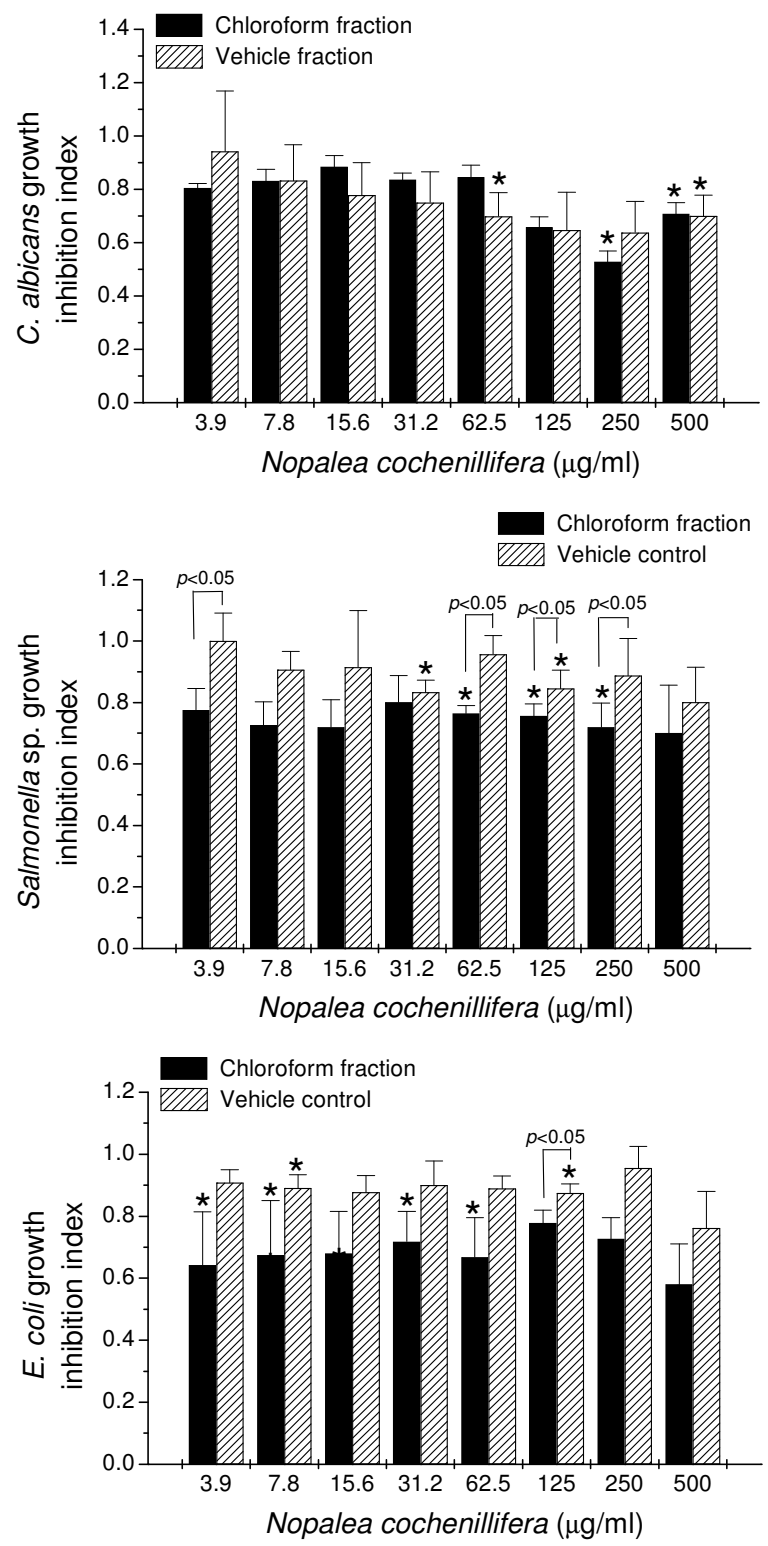

Fig. 2: Effect of fresh Nopalea chloroformic fraction on $C$. albicans, Salmonella enterica and $E$. coli growth. Candida albicans was adjusted to $1 \times 10^{3}$ yeasts $\mathrm{mL}^{-1}$ in $\mathrm{YM}$ broth and bacteria were adjusted to $2 \times 10^{3}$ bacteria $\mathrm{mL}^{-1}$ in ICC broth as explained in the text. Then bacteria and yeasts were cultured in the presence or absence of various concentrations of the Nopalea extracts or vehicle controls, for $24 \mathrm{~h}$ (yeasts) or $6 \mathrm{~h}$ (bacteria) at $37^{\circ} \mathrm{C}$, after which MTT was added to all wells and plates were incubated for 4 additional hours. At the end of the incubation period, extraction buffer was added to all wells and optical densities were read at $540 \mathrm{~nm}$ as detailed in the text. Data represent means \pm SEM of growth inhibition indexes of triplicates from 3 independent experiments. *, $\mathrm{P}<0.05$ as compared with untreated control

any other observed inhibitory effect was due to the vehicle. This fraction, however, caused 41 to 57 percent Salmonella enterica var. thyphimurium growth inhibition at the concentrations tested, but only the activity at $500 \mu \mathrm{g} \mathrm{mL}^{-1}$ (57.2 percent growth inhibition) was attributed to the effect of the fraction $(\mathrm{P}<0.05)$ 

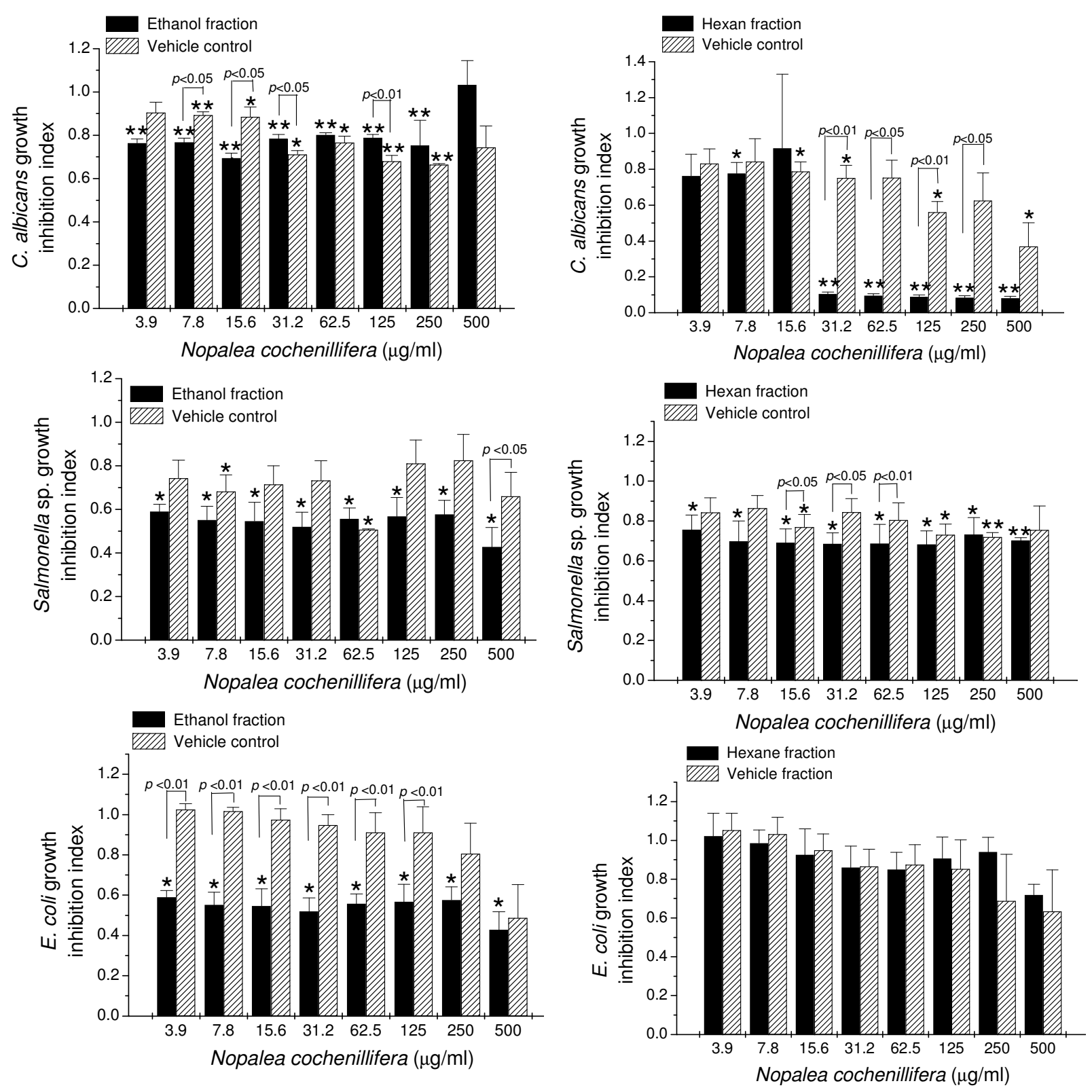

Fig. 3: Effect of fresh Nopalea ethanolic fraction on C. albicans, Salmonella enterica and $E$. coli growth. Candida albicans was adjusted to $1 \times 10^{3}$ yeasts $\mathrm{mL}^{-1}$ in $\mathrm{YM}$ broth and bacteria were adjusted to $2 \times 10^{3}$ bacteria $\mathrm{mL}^{-1}$ in ICC broth as explained in the text. Then bacteria and yeasts were cultured in the presence or absence of various concentrations of the Nopalea extracts or vehicle controls, for $24 \mathrm{~h}$ (yeasts) or $6 \mathrm{~h}$ (bacteria) at $37^{\circ} \mathrm{C}$, after which MTT was added to all wells and plates were incubated for 4 additional hours. At the end of the incubation period, extraction buffer was added to all wells and optical densities were read at $540 \mathrm{~nm}$ as detailed in the text. Data represent means \pm SEM of growth inhibition indexes of triplicates from 3 independent experiments. **, $\mathrm{P}<0.01$; $*, \mathrm{P}<0.05$ as compared with untreated control

when comparing the effect of the ethanolic fraction versus the vehicle control (Fig. 3); any other inhibitory effect was due to the vehicle. This fraction did not alter E. coli growth (Fig. 3).

Fig. 4: Salmonella enterica and E. coli growth. Candida albicans was adjusted to $1 \times 10^{3}$ yeasts $\mathrm{mL}^{-1}$ in $\mathrm{YM}$ broth and bacteria were adjusted to $2 \times 10^{3}$ bacteria $\mathrm{mL}^{-1}$ in ICC broth as explained in the text. Then bacteria and yeasts were cultured in the presence or absence of various concentrations of the Nopalea extracts or vehicle controls, for $24 \mathrm{~h}$ (yeasts) or $6 \mathrm{~h}$ (bacteria) at $37^{\circ} \mathrm{C}$, after which MTT was added to all wells and plates were incubated for 4 additional hours. At the end of the incubation period, extraction buffer was added to all wells and optical densities were read at $540 \mathrm{~nm}$ as detailed in the text. Data represent means \pm SEM of growth inhibition indexes of triplicates from 3 independent experiments. **, $\mathrm{P}<0.01$; $*, \mathrm{P}<0.05$ as compared with untreated control

Antimicrobial activity of dried $N$. cochenillifera hexanic fraction: As observed in Fig. 4, Nopalea hexanic fraction caused 8 to 92 percent $C$. albicans growth inhibition at the concentrations tested, 
Am. J. Infect. Dis., 2 (1): 1-8, 2006
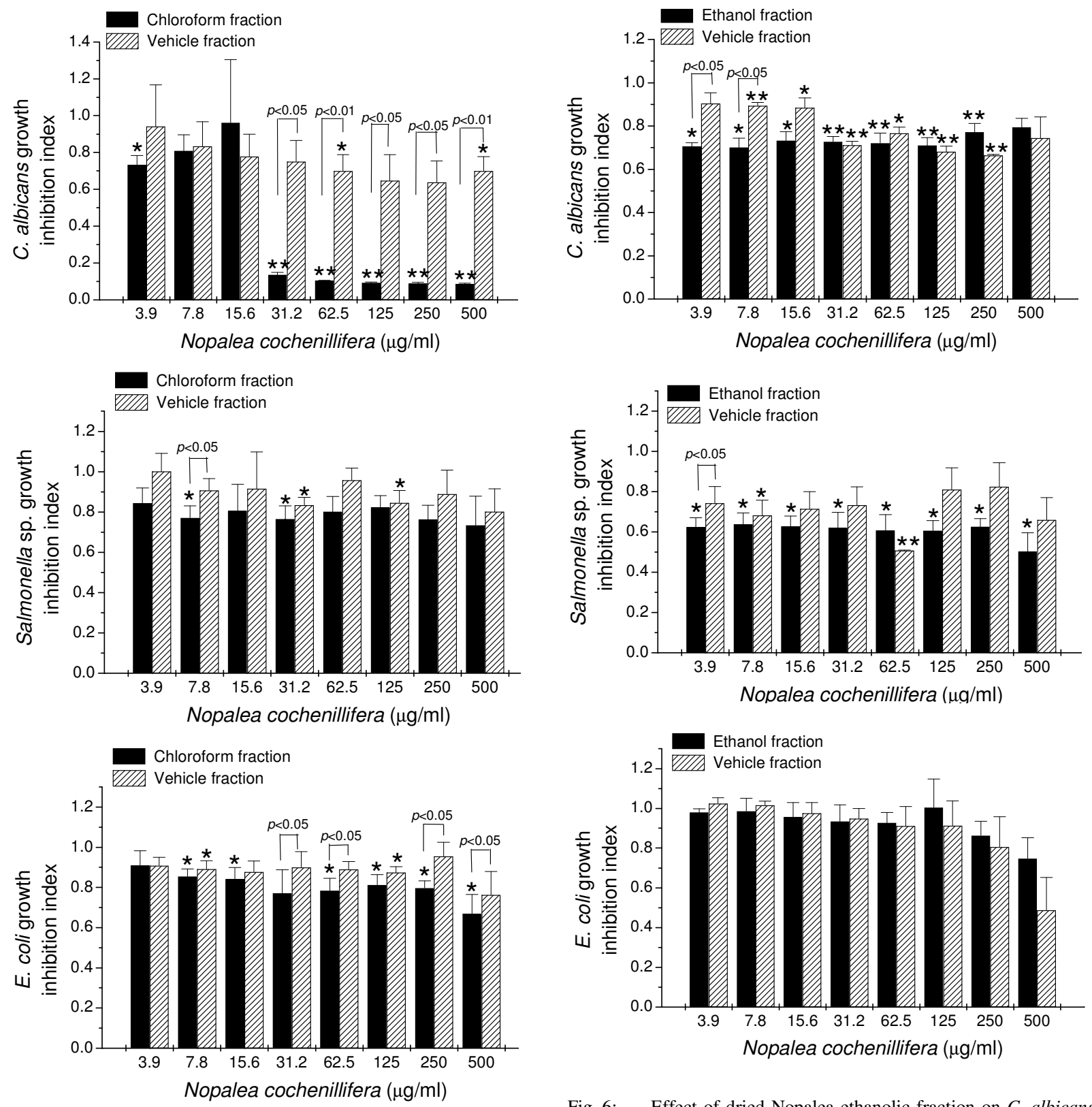

Fig. 5: Effect of dried Nopalea chloroformic fraction on $C$. albicans, Salmonella enterica and E. coli growth. Candida albicans was adjusted to $1 \mathrm{X} 10^{3}$ yeasts $\mathrm{mL}^{-1}$ in $\mathrm{YM}$ broth and bacteria were adjusted to $2 \times 10^{3}$ bacteria $\mathrm{mL}^{-1}$ in ICC broth as explained in the text. Then bacteria and yeasts were cultured in the presence or absence of various concentrations of the Nopalea extracts or vehicle controls, for $24 \mathrm{~h}$ (yeasts) or $6 \mathrm{~h}$ (bacteria) at $37^{\circ} \mathrm{C}$, after which MTT was added to all wells and plates were incubated for 4 additional hours. At the end of the incubation period, extraction buffer was added to all wells and optical densities were read at $540 \mathrm{~nm}$ as detailed in the text. Data represent means \pm SEM of growth inhibition indexes of triplicates from 3 independent experiments. **, $\mathrm{P}<0.01$; $*, \mathrm{P}<0.05$ as compared with untreated control

but only the activity at concentrations 31.2, 62.5, 125 and $250 \mu \mathrm{g} \mathrm{mL}^{-1}(89.5,90.5,91.1$ and 91.5 percent growth inhibition respectively) were attributed to the effect of this fraction $(\mathrm{P}<0.05)$ when comparing the

Fig. 6: Effect of dried Nopalea ethanolic fraction on C. albicans, Salmonella enterica and E. coli growth. Candida albicans was adjusted to $1 \mathrm{X} 10^{3}$ yeasts $\mathrm{mL}^{-1}$ in $\mathrm{YM}$ broth and bacteria were adjusted to $2 \times 10^{3}$ bacteria $\mathrm{mL}^{-1}$ in ICC broth as explained in the text. Then bacteria and yeasts were cultured in the presence or absence of various concentrations of the Nopalea extracts or vehicle controls, for $24 \mathrm{~h}$ (yeasts) or $6 \mathrm{~h}$ (bacteria) at $37^{\circ} \mathrm{C}$, after which MTT was added to all wells and plates were incubated for 4 additional hours. At the end of the incubation period, extraction buffer was added to all wells and optical densities were read at $540 \mathrm{~nm}$ as detailed in the text. Data represent means \pm SEM of growth inhibition indexes of triplicates from 3 independent experiments. **, $\mathrm{P}<0.01$; $*, \mathrm{P}<0.05$ as compared with untreated control

effect of the hexanic fraction versus the vehicle control (Fig. 4); any other observed inhibitory effect was due to the vehicle. This fraction also caused 24 to 32 percent Salmonella enterica var. thyphimurium growth inhibition at the concentrations tested, but only the 
activity at concentrations $15.6,31.2$ and $62.5 \mu \mathrm{g} \mathrm{mL}^{-1}$ $(30.9, \quad 31.5$ and 31.3 percent growth inhibition respectively) was attributed to the effect of the fraction $(\mathrm{P}<0.05)$ when comparing the effect of the hexanic fraction versus the vehicle control (Fig. 4); any other inhibitory effect was due to the vehicle. In contrast, this fraction did not alter $E$. coli growth at all concentrations tested (Fig. 4).

Antimicrobial activity of dried $N$. cochenillifera chloroformic fraction: As observed in Fig. 5, Nopalea chloroformic fraction caused 4 to 91 percent $C$. albicans growth inhibition at the concentrations tested, but only the activity at concentrations $31.2,62.5,125$, 250 and $500 \mu \mathrm{g} \mathrm{mL}^{-1}(86.4,89.5,90.8,91$ and 91.2 percent growth inhibition respectively) were attributed to the effect of this fraction $(\mathrm{P}<0.05)$ when comparing the effect of the chloroformic fraction versus the vehicle control (Fig. 5); any other observed inhibitory effect was due to the vehicle. This fraction also caused 16 to 27 percent Salmonella enterica var. thyphimurium growth inhibition at the concentrations tested, but only the activity at $7.8 \mu \mathrm{g} \mathrm{mL} \mathrm{m}^{-1}$ (23 percent growth inhibition) was attributed to the effect of this fraction (P $<0.05$ ) when comparing the effect of the chloroformic fraction versus the vehicle control (Fig. 5); any other inhibitory effect was due to the vehicle. This fraction was also associated with 9 to 33 percent $E$. coli growth inhibition at the concentrations tested, but only the activity at the concentrations 31.2, 62.5, 250 and 500 $\mu \mathrm{g} \mathrm{mL} L^{-1}(23,22,20$ and 33 percent growth inhibition respectively) was attributed to the effect of the fraction $(\mathrm{P}<0.05)$ when comparing the effect of the chloroformic fraction versus the vehicle control (Fig. 5); any other inhibitory effect was due to the vehicle.

Antimicrobial activity of dried $N$. cochenillifera ethanolic fraction: As observed in Fig. 6, Nopalea ethanolic caused 20 to 30 percent $C$. albicans growth inhibition at the concentrations tested, but only the activity at concentrations 3.9 and $7.8 \mu \mathrm{g} \mathrm{mL}^{-1}$ (29.4 and 30 percent growth inhibition respectively) were attributed to the effect of this fraction $(\mathrm{P}<0.05)$ when comparing the effect of the ethanolic fraction versus the vehicle control (Fig. 6); any other observed inhibitory effect was due to the vehicle. This fraction also caused 36 to 50 percent Salmonella enterica var. thyphimurium growth inhibition at the concentrations tested, but only the activity at $3.9 \mu \mathrm{g} \mathrm{mL} \mathrm{m}^{-1}$ (37.6 percent growth inhibition) was attributed to the effect of this fraction (P $<0.05)$ when comparing the effect of the ethanolic fraction versus the vehicle control (Fig. 6); any other inhibitory effect was due to the vehicle. In contrast, this fraction did not alter $E$. coli growth at all concentrations tested (Fig. 6).

\section{DISCUSSION}

Medicinal plants have become part of complementary medicine worldwide, because of their potential health benefits. Plants have been used for centuries in the medical practices mostly in therapy of diverse pathologies ${ }^{[20]}$. Nopal is widely used in Mexico as a treatment for glucose control ${ }^{[21]}$ and is known in the United States as prickly pear cactus. $N$. cochenillifera pads are rich in vitamin A and have been used for headaches, eye troubles and insomnia if consumed as a tea ${ }^{[21]}$. In addition, the split pads are emollient and used as poultices on rheumatism and baked for ulcers, gout and wounds. This plant is good for warts, kidney problems, measles and as a vermifuge for gastro-intestinal parasites, used sparingly. Other studies suggest that nopal stems and fruit might have anti-inflammatory, pain-relieving and stomachprotective effects ${ }^{[15]}$. However, important validation of its antimicrobial properties has not been fully determined. Some reports have shown inhibition of herpes simplex virus type 1 infection by $N$. cochenillifera $^{[17]}$ and antiviral activity of Opuntia streptacantha ${ }^{[21]}$.

In our study, we showed that this cactus possesses antibiotic activity against Candida albicans, Escherichia coli and Salmonella enterica var. thyphimurium, which can cause persistent disease in human immunodeficiency virus type 1-infected people and other immunocompromised individuals ${ }^{[22,23]}$. We showed that hexanic and chloroformic fractions of dried $N$. cochenillifera were more effective than fresh pads in inhibiting Candida albicans growth; this may indicate a greater availability of the active compounds in the dried material (other benefits are the widespread use this material for traditional healers, it is easier to work with than fresh material and there are few problems associated with the large scale extraction) compared with the fresh pads and also gives indication of the nonpolar nature of the involved compounds. The use of immunosuppressive drugs, the spread of AIDS and in general acquired immunosuppression, have resulted in an increasing occurrence of opportunistic systemic mycoses. Candidiasis of the esophagus and mouth by Candida albicans, is the most common infection observed in the immunosuppressed individual ${ }^{[24]}$. Because there are limited effective antifungal drugs currently available for the treatment of candidiasis, it is critical to discover and evaluate new sources of antifungal agents. $N$. cochenillifera-derived natural products may be of potential interest for novel antifungal agents. In addition, lower chloroformic and ethanolic concentrations of dried $N$. cochenillifera than those of fresh pads were needed to inhibit Salmonella enterica var. thyphimurium growth; this indicates that the putative bioactive compounds may become more available in the dried vegetal material and that both polar (proteins and sugars) and non-polar (mainly lipids) compounds are involved in this antibacterial activity. Additionally, only chloroformic fraction of both dried and fresh $N$. cochenillifera pads were capable to inhibit $E$. coli growth. In this case, non-polar 
compounds from both dried and fresh pads are probably involved in the antimicrobial activity observed. Both Salmonella enterica var. thyphimurium and E. coli are well recognized not only to commonly cause gastrointestinal disorders, but also induce opportunistic infections in AIDS individuals ${ }^{[25,26]}$. Morbidity and mortality caused by bacterial infections importantly decreased upon the discovery and clinical use of antibacterial agents. However, nowadays public health faces the challenge of increasing mechanisms of antibiotic resistance of bacteria, because of the continuous and uncontrolled usage of antibacterial agents $^{[27]}$. These mechanisms include decreased drug accumulation and permeability and modification of the antibiotic $^{[28]}$.

Plant antimicrobials are not currently used systemically because of their low activity, particularly against gram-negative bacteria. These compounds are usually classified as "antimicrobial" if they produce minimal inhibitory concentrations in the range of 100 to $1000 \mu \mathrm{g} \mathrm{mL}^{-1}$, which are still higher than those of typical bacterial and fungal antibiotics (0.01 to $10 \mu \mathrm{g}$ $\left.\mathrm{mL}^{-1}\right)^{[29]}$. However, in our study we have shown that some of Nopalea extracts possessed antimicrobial activity at concentrations as low as $7.8 \mathrm{mg} \mathrm{mL}^{-1}$ (Fig. 2, 5 and 6), which may be an indication of a potent antibiotic activity of such extracts and may be of physiological relevance ${ }^{[30]}$. Because of this, isolation and evaluation of novel antimicrobial agents from plants, particularly, N. cochenillifera, may lead to the discovery of natural antibiotics for which bacteria and other organisms are susceptible. In preliminary studies, we have observed that $N$. cochenillifera pads are rich in flavonoids and tannins (data not shown) which may be related to their biological activity. To our knowledge, this is the first report showing that Nopalea extracts affect bacteria and yeast growth. However, more investigations are needed to isolate and identify the molecular structure of the biologically active substances in $N$. cochenillifera. There are still a number of plant compounds that remain to be evaluated at the molecular, cellular and physiological levels for their potential to treat human diseases. Further studies are underway to evaluate the Nopalea's extract and active compounds in vivo in a murine model of infection and to characterize the antimicrobial active compound (s).

\section{ACKNOWLEDGMENT}

This work was supported by grants 43019/A-1 from Consejo Nacional de Ciencia y Tecnología (CONACYT) and CN-887-04 from Programa de Investigación Científica y Tecnológica (PAICYT), Universidad Autónoma de Nuevo León (UANL), México to RGF and grant 20000606001 from CONACYT (SIREYES) to LHM.

\section{REFERENCES}

1. Bravo, H.H., 1978. Las cactáceas de México. Universidad Nacional Autónoma de México, México, D. F., 2nd Ed.n, Vol. 1.

2. Barthlott, W. and D.R. Hunt, 1993. Cactaceae. In: The Families and Genera of Vascular Plants (Eds. K. Kubitzki, J.G. Rohwe, and J.V. Bittrich), pp: 161-167. Springel-Verlag, Berlin.

3. Guzmán, C.L.U., 1997. Grupos taxonómicos. In: Suculentas Mexicanas/Cactáceas, pp: 37-41. CVS Publicaciones, México, D.F.

4. Russell, Ch.E. and P. Felker, 1987. The pricklypears (Opuntia sp., Cactaceae): A source of human and animal food in semiarid regions. Econ. Bot., 41: 433-445.

5. Pimienta, B.E., 1993. Vegetable cactus. In: (Ed J.T. Williams), pp: 177-192. Chapman and Hall, London, England.

6. Mick, R.J., 1991. Growing variety 1308 for year around nopalito production. In: (Ed. P. Felker), pp: 32-35. 2nd Annual Texas Prickly Pear Council Convention Proceedings, McAllen, Texas, USA.

7. Muñoz de Chavez, M., A. Chavez, V. Valles and J.A. Roldan, 1995. The nopal: A plant of manifold qualities. World Rev. Nutr. Diet., 77: 109-134.

8. Rodriguez-Felix, A. and M. Cantwell, 1988. Developmental changes in composition and quality of prickly pear cactus cladodes (nopalitos). Plant Foods Hum. Nutr., 38: 83-93.

9. Nerd, A., M. Dumotier and Y. Mizrahi, 1997. Properties and postharvest behavior of the vegetable cactus Nopalea cochenillifera. Postharvest Biol. Tec., 10: 135-143.

10. Frati-Munari, A.C., E. Altamirano-Bustamante, N. Rodriguez-Barcenas, R. Ariza-Andraca and R. Lopez Ledesma, 1989. Hypoglycemic action of Opuntia streptacantha Lemaire: study using raw extracts. Arch. Invest. Med. (Mex)., 20: 321-325.

11. Britton, N.L. and J.N. Rose, 1919-1923. Cactaceae: Descriptions and Illustrations of Plants of the Cactus Family. Carnegie Institution of Washington, Washington, D.C.

12. Morton, J.F., 1981. Atlas of the medicinal plants of middle America (Bahamas to Yucatan). Charles C. Thomas Publishers, Springfield (Illinois).

13. Loro, J.F., I. del Río and L.P. Pérez-Santana, 1999. Preliminary studies of analgesic and antiinflammatory properties of Opuntia dillenii aqueous extract. J. Ethnopharmacol., 67, 213-218.

14. Mabberley, D.J., 1997. The Plant Book: A Portable Dictionary of the Vascular Plants, Cambridge University Press: Cambridge, 2nd Edn.

15. Park, E.H, J.H. Kahng and E.A. Paek, 1998. Studies on the pharmacological action of cactus: identification of its anti-inflammatory effect. Arch. Pharm. Res., 21: 30-34. 
16. Park, E.H. and M.J. Chun, 2001. An antiinflammatory principle from cactus. Phytotherapy, 72: $165-167$.

17. Szuchman, A., J. Tal and Y. Mizrahi, 1999. Antiviral properties in cladodes of the cactus Nopalea cochenillifera (L.). In: XVI International Botanical Congress, Israel. Abstract 5409, poster 2429.

18. Gomez-Flores, R., S. Gupta, R. Tamez-Guerra and R.T. Mehta, 1995. Determination of MICs for Mycobacterium avium-M. intracellulare complex in liquid medium by a colorimetric method. $\mathrm{J}$. Clin. Microbiol., 33: 1842-1846.

19. Borchers, A.T., C.L. Keen, J.S. Stern and M.E. Gershwin, 2000. Inflammation and native american medicine: the role of botanicals. Am. J. Clin. Nutr., 72: 339-347.

20. Roman-Ramos, R., J.L. Flores-Saenz and J.L. Alarcon-Aguilar, 1995. Anti-hyperglycemic effect of some edible plants. J. Ethnopharmacol., 48: 2532.

21. Ahmad, A., J. Davies, S. Randall and G.R.B. Skinner, 1996. Antiviral properties of extract of Opuntia streptacantha. Antiviral Res., 30: 75-85.

22. Mofenson, L.M., J. Oleske, L. Serchuck, R. Van Dyke, C. Wilfert; CDC; National Institutes of Health; and Infectious Diseases Society of America, 2004. Treating opportunistic infections among HIV-exposed and infected children: recommendations from $\mathrm{CDC}$, the National Institutes of Health, and the Infectious Diseases Society of America. MMWR Recomm. Rep. 53 (RR-14): 1-92.

23. Carcamo, C., T. Hooton, M.H. Wener, N.S. Weiss, R. Gilman, J. Arevalo, J. Carrasco, C. Seas, M. Caballero and K.K. Holmes, 2005. Etiologies and manifestations of persistent diarrhea in adults with HIV-1 infection: A case-control study in Lima, Peru. J. Infect. Dis., 191: 11-19.
24. Leigh, J.E., K. Shetty and P.L. Fidel, 2004. Oral opportunistic infections in HIV-positive individuals: review and role of mucosal immunity. AIDS Patient Care STDS 18: 443-456.

25. Ruiz-Contreras, J., J.T. Ramos, T. HernandezSampelayo, M.D. Gurbindo, M. Garcia de Jose, M.J. de Miguel, M.J. Cilleruelo and M.J. Mellado, 1995. Sepsis in children with human immunodeficiency virus infection. The Madrid HIV Pediatric Infection Collaborative Study Group. Ped. Infect. Dis. J., 14: 522-526.

26. Lynne, M.M., J. Oleske, L. Serchuck, R. Van Dyke and C. Wilfert, 2005. Treating opportunistic infections among HIV-exposed and infected children: Recommendations from CDC, the National Institutes of Health, and the Infectious Diseases Society of America. Clin. Infect. Dis., 40: S1-S84.

27. Russell, A.D., 2000. Introduction of biocides into clinical practice and the impact on antibioticresistant bacteria. J. Appl. Microbiol., 92: 121S$135 \mathrm{~S}$.

28. Moreillon, P., 2000. Means of bacterial resistance. Rev. Med. Suisse Romande, 120 : 641-650.

29. Tegos, G., F.R. Stermitz, O. Lomovskaya and K. Lewis, 2002. Multidrug pump inhibitors uncover remarkable activity of plant antimicrobials. Antimicrob. Agents Chemother., 46: 3133-3141.

30. Drusano, G.L., 2004. Antimicrobial pharmacodynamics: critical interactions of "bug and drug". Nat. Rev., 2: 289-300. 